\title{
Effect of Celebirity Endorsement on Consumers Purchase Intention in the Mediation Effect of Brand Image ${ }^{1}$
}

\author{
Reem ALAWADHi iD a Müge ÖRS iD b \\ a Istanbul Aydin University, İstanbul, Turkey. reem.alawdhi@gmail.com \\ b Istanbul Aydin University, İstanbul, Turkey. mugeors@aydin.edu.tr
}

\begin{tabular}{|c|c|}
\hline ARTICLE INFO & ABSTRACT \\
\hline $\begin{array}{l}\text { Keywords: } \\
\text { Celebrity Endorsement } \\
\text { Expertise } \\
\text { Likeability } \\
\text { Brand Image } \\
\text { Purchase Intention }\end{array}$ & $\begin{array}{l}\text { Purpose - This research clarifies how Yemeni consumers perceive celebrity endorsement and examines } \\
\text { the influence of celebrity attributes (Trustworthiness, Expertise, Attractiveness and likeability) on Yemeni } \\
\text { consumer's purchase intention in terms of brand image. Moreover, The direct influence of the brand image } \\
\text { on the intention of consumer purchases. } \\
\text { Design/methodology/approach - This research has been designed and implemented using the } \\
\text { quantitative research method. The survey community was identified in Yemen; a total of } 282 \text { respondents } \\
\text { have collected. Modeling of structural equations (SEM) has been used to demonstrate and analyze the } \\
\text { relationship among variables. } \\
\text { Findings - Research findings some hypotheses associated with this study were accepted (celebrity } \\
\text { expertise, celebrity likeability) where celebrity had a major influence on the intent of purchase for the } \\
\text { consumer in terms of brand image. While the others were rejected (celebrity trustworthiness, celebrity } \\
\text { attractiveness), It was also found that there is an important and direct correlation between brand image } \\
\text { and customer buying intention. } \\
\text { Discussion - In choosing a celebrity to endorse the brand marketers have to be cautious because the right } \\
\text { qualities of the endorsement often contribute to the consumer's interest and the desire to purchase the } \\
\text { item. For Yemeni consumer advertisers should concentrate more on the expertise of celebrities and the } \\
\text { likeability of celebrities to enhance the brand image which ultimately leads to increased consumer buying } \\
\text { intent. }\end{array}$ \\
\hline
\end{tabular}

\section{INTRODUCTION}

Most companies want to use the right strategy to build a successful and unforgettable name for their brand to ensure its success, survival, growth and prosperity. In fact, lots of researches have proven this practice always getting the customer's admiration and making great feedback toward the advertisement. Celebrity endorsement is a marketing communication strategy that firms use to attract customers, influence their decision and encourage them to buy that brand (Chavda V. , 2010). Using celebrities empowers companies to create innovative ads and achieve a positive effect on the brand's attitude and sales strategy (Ranjbarian et al., 2010).

In the present era celebrity endorsement deemed a million of dollars industry (Kambitsis et al., 2002). Companies expenditure a huge amount of money to associate their brands with a celebrity's image. However, celebrity endorsement can be a valuable support for businesses looking for better brand awareness or a higher return. The firm's decision to select celebrities should be a wise one. Consumers or targeted groups notice a direct engagement between the celebrity image and its brand. As well-known there is no strategy without risk, Celebrity endorsement as a strategy adopted by the right celebrity companies and their endorsement alongside representatives will have a positive effect. (Foong and Yazdanifard, 2014).

${ }^{1}$ This article was produced from the master thesis of Reem Alawadhi in the semester of 2019-2020 Fall at Istanbul Aydin University. 


\section{R. Alawadhi - M. Örs 12/1 (2020) 454-468}

\subsection{Problem Statement}

The biggest problem with the celebrity endorsement strategy is selecting an appropriate celebrity endorser that aligns with the brand to obtain an effective and successful advertisement campaign. The previous studies were conducted in this field concluded there is a positive correlation between celebrity endorsements and purchasing intentions of consumers. However, those researches have been done in several countries with a diverse group of consumers. The current study aims to determine the perception of Yemeni consumers of celebrity endorsement and the effect of celebrity endorsement on Yemeni consumers ' buying intent as regards brand image.

\subsection{Purpose of Research}

This research has been chosen to achieve the following aims:

- Examine the perception of Yemeni consumer's toward celebrity endorsements.

- Determine the factors and attributes of celebrity that influence the intent of purchase for Yemeni consumer's in terms of brand image.

- Finds the brand image's impact as a mediator between celebrity endorsement and the consumer's intention to buy.

- Examine the direct effect of brand image on consumer buying intent.

\subsection{Research Questions}

This study is predicated on the following questions:

Question 1: How do Yemeni consumers perceive celebrity endorsement?

Question 2: What are the influences of celebrity trustworthiness, expertise attractiveness and likeability on Yemeni consumers ' buying intentions when a brand image was used as a mediator to purchase a product?

Question 3: What is the relationship between the image of the brand and the purchase intention of the consumer?

\section{LITERATURE REVIEW}

\subsection{Celebrity Endorsement}

Celebrity is people who are known for large groups of people through their characteristics, skills, attractiveness and lifestyle, and getting a high degree of attention from audiences. Celebrities can be people from television, movies, artists and sports, or can be untraditional celebrities as business, politics, or even person from the military (McCracken, 1989). Celebrity endorsers defined as a person "inviter" who invite the people to purchase the product or service due to their distinctive position and credibility that leads towards intention to purchase (Jamil, 2014).

Celebrity Endorsement is one of those powerful tools that advertisers are seeking to exploit celebrity image and reputation to promote their brand. Use celebrity endorsement in ads reinforces the message in target customers ' minds more than when other approaches are used. Moreover, celebrity endorsement function help to boost up the sales of endorsed brands where consumers prefer to buy the brand more if endorsed by their favorite celebrity (Deepa and Giridhar, 2018).

\subsection{Celebrity Endorsement Effectiveness}

Most research in this field seeks to identify the most critical factors for determining the efficacy of celebrity endorsement. In general, the effectiveness of Celebrity endorsements has two simple source models that considered the most important sources in the celebrities context:

- The model of credibility is established by Hovland and Weiss in (1953), the perceived credibility of the communicator was analyzed by them and they found that there are two factors trustworthiness and expertness are the concept of credibility source.

- The model of attractiveness was improved by McGuire in (1985) who stated that attractiveness as general meaning which includes such criteria as likeability, similarity and familiarity. 


\section{R. Alawadhi - M. Örs 12/1 (2020) 454-468}

As fact in the advertising context, attractiveness could be considered as a third component of source credibility according to (Ohanian, 1990). Such models each have certain specific attributes, the suggestion could be allowed as a base for selection of celebrity endorsement. For this study, four dimensions were chosen from literature to measure celebrity endorsement effectiveness

\subsubsection{Celebrity Trustworthiness}

Trustworthiness is an indicator of an endorser's believability and integrity. This points to the trust of the consumers in the source of information in an honest and objective method (Choi and Rifon, 2011). The most successful and profitable way to make the customer more optimistic about the brand is to create a degree of trustworthiness (Hakimi et al., 2011). Choosing a celebrity who has powerful trustworthiness, integrity, and reputation criteria by advertisers (Shimp, 2003). Additionally, the celebrity's good faith can influence the value understanding of customers and further affect their purchasing choice (Erdem and Swait, 2004).

\subsubsection{Celebrity Expertise}

Expertise is the knowledge and skill level the endorser possessed (Hovland et al., 1953). It means the ability of celebrities to provide knowledge to others based on their background, education, skills or efficiency, this constitutes a person's qualifications (Horai et al., 1974). The semantic expertise scales includes expert, experienced, knowledgeable, qualified and skilled (Ulkhaq et al., 2016). The expert celebrity consider more persuasive and can have an effect on the decision to purchase goods than non-experts, Ohanian argued that attractiveness and trustworthiness have less effect on customer purchasing intentions than celebrity endorsers ' expertise. (Ohanian, 1990).

\subsubsection{Celebrity Attractiveness}

Attractiveness indicates to the criteria that attract audiences to an endorser. Attractive, classy, nice, stylish and sexy these terms are generally used to assess the physical attractiveness of celebrity people (Ohanian, 1991).

Marketers believe that beauty can increase the chances of selling thus completely used attractive celebrity endorsers in their advertisements (Said and Napi, 2015). The attractive celebrity improves the image of an advertised brand (Baker and Churchill, 1977). In interpersonal marketing sales, The beauty and charisma that an attractive individual owned can be more influential and powerful than an unattractive individual (Reingen et al.,1980). Furthermore, the celebrity's good appearance will attract potential customers and convince them to be brand customers.

\subsubsection{Celebrity Likeability}

Likeability is "affection for the endorser due to their physical appearance and behaviour" (Erdogan, 1999). The consumer's liking for the endorser impressed by the endorser's external appearance, qualification and behavior (McGuire, 1969). Celebrities are likable because they have similar beliefs to those of the audience (Vaghela, 2013). There are various attributes that embody likeability for a celebrity such values as personality, attitude, intellectual skills and fashion style (Byun, 2014).

People would like to be like celebrities. The fame and success stories of celebrities are inspirations for most of their followers. Wherefore, celebrity fans try to imitate them in their behaviors or even seek to change their physical appearance, just to appear similar to the celebrity just slightly.

Several types of research mentioned that advertising liking is one of the main predictors of brand liking (Thorson, 1991). Dubitsky and Walker Showed that celebrity likeability plays an important role in supporting consumer responsiveness towards advertising, which could create an opportunity for efficient commercial leading to positive attitudes towards the advertised brand, which raise purchasing intent (Dubitsky and Walker, 1994).

\subsection{Brand Image}

Brand image is consumer perception about a brand. It is referred to as the mark's outstanding image in consumers' minds (Aaker, 1997). The image of the brand reflects a passion for a product, this illustrates how a particular 


\section{R. Alawadhi - M. Örs 12/1 (2020) 454-468}

product or service positions in the minds of the consumers. Also, showing the identity of a brand in its consumers ' minds (Keller, 2003).Companies have to be sure that their mission and visions become a part of their brand image. Commonly the image of the brand is formed based on a unique idea that consumer has about a brand. For example, Toyota is correlated with reliability while Volvo is correlated with safety (Agrawal and Dubey, 2012). Marketers should be sure that the idea related to the brand image is not just about the customer making a purchase but also the perception attached to the purchase (Ind, 2007).

Building a powerful brand image is primary in modern-day business environments, being an efficient way to describe the brand in the midst of media rush and clutter. Koshy and Manohar Have done study in the "Influence of Celebrity Endorsement on Brand Image of Grooming Products" they found that celebrity endorsements offer a brand a touch of glamor and the expectation that a famous character in a rival market would offer added appeal and awareness of the name. Besides, this helps to boost the brand's recall value, thereby giving consumers a favorable attitude towards celebrity endorsements (Koshy and Manohar, 2017).

\subsection{Consumer Purchase Intention}

Purchase intention is the consumer's preference for buying a product or service (Rasheed et al., 2015). Intention to buy described as a method of decision-making that examine the consumer's justification for buying a particular brand (Sallam, 2012). The purchase decision of a customer is a complex process. The intention of purchase is usually linked to consumer perceptions, behavior and attitudes. Purchase behavior considers a basic point to access and analysis a particular product for consumers (Ghosh,1990). In the recommendation context, the user's willingness to buy a certain product recommended by the recommender. Increase willingness to purchase a product means the probability to buy it but not necessarily to actually purchase it. On the obverse, a lower willingness does not mean an impossibility to buy (Roudposhti, et al., 2018).

\section{CONCEPTUAL FRAMEWORK AND HYPOTHESIS}

The research examines the relationships between the characteristics of celebrity endorsement as independent variables on one hand, and the consumer's intention to purchase as a dependent variable on the other, these relationships are mediated by the brand image. This research adopted the conceptual framework model from previous research conducted by (Mansour and Diab, 2016). The following model has been presented in order to achieve this objective.

Figure 1: Conceptual Framework

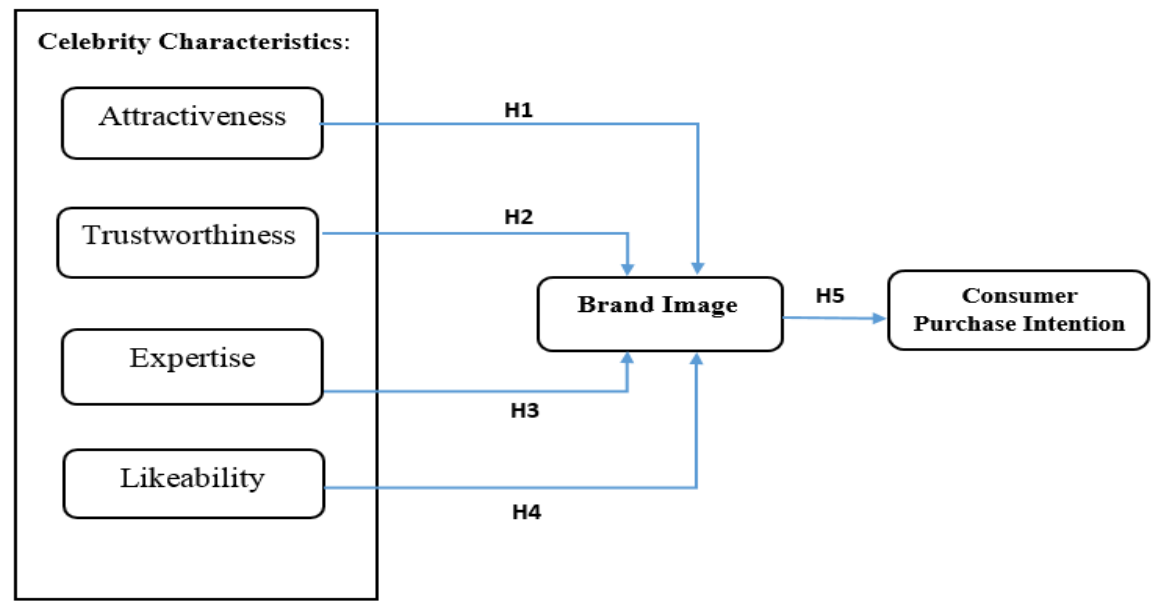

The hypotheses for analysis are as follows, in accordance with this study's conceptual framework context:

\subsection{Celebrity Attractiveness}

Attractive people are more convincing than unattractive people in changing beliefs (Ohanian, 1991). According to Sallam's study, the attractiveness of the celebrity endorser affects strongly and positively the intention to buy consumers (Sallam, 2012). Furthermore, Hudha and Hidayat concluded that celebrity's attractiveness in television 


\section{R. Alawadhi - M. Örs 12/1 (2020) 454-468}

advertising has a strong relationship with customers and a favorable effect on the actions of consumers in Indonesia in terms of brand choice (Hudha and Hidayat, 2009). The following hypothesis is therefore formulated in order to test this statement:

$H_{1}$ : There is a positive relationship between celebrity attractiveness and consumer purchase intention in terms of brand image.

\subsection{Celebrity Trustworthiness}

Baseheart and Miller's study suggested that consumers ' perceptions towards a brand and their buying habits could be modified if the target customers find the source of the message to be reliable and trustworthy (Baseheart and Miller, 1969). As well as Gupta and his friends revealed that trustworthiness has a significant effect on the buying intentions of Indian consumers (Gupta et al, 2015). The following hypothesis is therefore formulated in order to test this statement:

$\mathrm{H}_{2}$ : There is a positive relationship between celebrity trustworthiness and consumer purchase intention in terms of brand image.

\subsection{Celebrity Expertise}

Expertise is a senior part of the credibility model, several earlier studies have shown that expertise affects the buying intention significantly (Eisend and Langner, 2010). Moreover, that a Celebrity's perceived expertise may result in a favorable attitude change toward brand thus directly influence on the purchasing intentions of consumers (Erdogan, 1999). Hence, the following hypothesis is formulated to test this statement:

$H_{3}$ : There is a positive relationship between celebrity expertise and consumer purchase intention in terms of brand image.

\subsection{Celebrity Likeability}

Based on the results of many previous studies, the likeability of this sample was used as a separate construct, distinct from the attractiveness of the endorser. The celebrity likeability increases the attention toward the brand that enhances the brand liking which influences consumer purchase intention (Patel and Parmar, 2015). As well, the likeability of celebrities has the biggest influence on the intent of consumers to buy (Maddux and Rogers, 1980). For testing this statement, the following hypothesis is formulated:

$H_{4}$ : There is a positive relationship between celebrity likeability and consumer purchase intention in terms of brand image.

\subsection{Brand Image}

Managers always need to raise buying intention by enhancing the brand image. According to Onwujiariri, The relation between celebrity endorsement and image of a brand in Port Harcourt's fast food industry is positive and secure (Onwujiariri et al., 2015). Having a good customer-specific brand identity plays a major role in maintaining brand awareness and brand loyalty that ultimately has a positive influence on the decision to buy and even postpurchase related products or services (Shah H. , et al., 2012) while (Zeeshan, 2013) discovered that the brand image has a major impact on men's buying intention. Obviously high brand awareness is more likely to result in a high brand association in the minds of customer that directly contribute to a decision to purchase the brand. The following hypothesis is therefore formulated in order to test this statement:

H5: There is a significant and positive relationship between brand image and purchase intention. 


\section{RESEARCH METHODOLOGY}

This research has been designed and implemented using the quantitative research method. The online selfadministered questionnaire used in this study composed of 5 point likert scale. Ranging as follows: (1= strongly disagree, 2 = disagree, 3 =Neither Agree nor disagree, 4 = agree and 5 = strongly agree) (Saunders et al., 2009).

The online questionnaire was created by Google forms and available both in Arabic and English languages, then distributed among Yemeni consumers. Convenient sampling method was used for sample selection. The multiple regression techniques need a large sample size for generalization objective and recommends using the following formula suggested by (Tabachnick \& Fidell, 2007): $\mathrm{N}>50+8 \mathrm{~m}$ Where: $(\mathrm{N}=$ sample size, $\mathrm{m}=$ number of independent variables)(Pallant, 2013). Based on the above formula the current research required sample size approximately $\mathrm{N}$ $>82$ whereas the number of independent variables is four. In another way, according to Hoelter's index, an appropriate sample size for the SEM method should exceed 200. As it represents the data in an adequate way (Byrne, 2016). Consequently, current research required to obtain at least 200 responses to achieve both requirements above-mentioned.

Factor analysis and Structural Equation Modeling statistical techniques were used to analysis this research. Factor analysis is a statistical technique that has three uses. Firstly, reduce a large number of data to a smaller group of variables. Secondly, establishes and explores underlying dimensions between measured variables and latent constructs. Thirdly, provides structure validity evidence (Williams, Onsman, \& Brown, 2010). Factor analysis classified into two principal classes: Exploratory Factor Analysis (EFA) and Confirmatory Factor Analysis (CFA). The two first use of factor analysis conducts by EFA whereas the third use conducts by CFA. SEM "is testing various theoretical models, that hypothesize how sets of variables define constructs and how these constructs are related to each other in a quantitative manner" ( (Schumacker and Lomax, 2010). SEM examines the structural path between variables whereas CFA confirms the relationship between latent and observed variables. IBM SPSS version 21 and IBM SPSS AMOS version 23 statistical software were used for data analysis. The following coding terminolog was used in the data analysis: (PhyAttract is Attractiveness, TurstW is Trustworthiness, Expert is Expertise, like is Likeability, Bimage is Brand Image and PurchasInt is Purchase Intention).

\section{ANALYSIS AND DISCUSSION}

\subsection{Demographic Profile of Respondents}

The sample of the study consisted of 282 responses. $52.8 \%$ of the respondents were male and $47.2 \%$ of the respondents were female. The ages range from 18 to 45 years and above. Whereas most respondents were within $18-24$ years. Furthermore, $64.2 \%$ of the participants were single. The majority of the respondents were students $62.8 \%$. As well most of them from undergraduate which represent $55.3 \%$ and $45 \%$ of respondents were earning less than $200 \$$.

Table 1: Demographic respondents

\begin{tabular}{lllll}
\hline Demographics Profile & Variables & Frequency & Percent & Cumulative Percent \\
\hline Gender & Male & 149 & 52.8 & 52.8 \\
\multirow{3}{*}{ Age } & Female & 133 & 47.2 & 100.0 \\
\cline { 2 - 5 } & under 18 & 6 & 2.1 & 2.1 \\
& $18-24$ & 145 & 51.4 & 53.5 \\
& $25-34$ & 82 & 29.1 & 82.6 \\
\multirow{3}{*}{ Education } & $35-40$ & 36 & 12.8 & 95.4 \\
& 45 or more & 13 & 4.6 & 100.0 \\
\cline { 2 - 5 } & High school or less & 61 & 21.6 & 21.6 \\
& Undergraduate(Bachelor's degree) & 156 & 55.3 & 77.0 \\
& Graduate degree (master's, PhD) & 65 & 23.0 & 100.0 \\
\cline { 2 - 5 } & & & & \\
& & & &
\end{tabular}




\begin{tabular}{|c|c|c|c|c|}
\hline \multirow{3}{*}{ Marital Status } & \multicolumn{3}{|c|}{ R. Alawadhi - M. Örs 12/1 (2020) 454-468 } & \multirow[b]{2}{*}{64.2} \\
\hline & Single & 181 & 64.2 & \\
\hline & Married & 101 & 35.8 & 100.0 \\
\hline \multirow[t]{2}{*}{ Employment Status } & Student & 177 & 62.8 & 62.8 \\
\hline & Employee & 27 & 9.6 & 72.3 \\
\hline \multirow{7}{*}{ Income per month } & Retired & 71 & 25.2 & 97.5 \\
\hline & Unemployed & 4 & 1.4 & 98.9 \\
\hline & Unable to work & 3 & 1.1 & 100.0 \\
\hline & less than $200 \$$ & 127 & 45.0 & 45.0 \\
\hline & $200 \$-500 \$$ & 85 & 30.1 & 75.2 \\
\hline & $500 \$-1000 \$$ & 42 & 14.9 & 90.1 \\
\hline & more than $1000 \$$ & 28 & 9.9 & 100.0 \\
\hline
\end{tabular}

According to Table 2 and Table 3,61\% of the Yemeni consumers have been aware of a brand just because of a celebrity-endorsed it. That means Yemeni consumers have positive attitude to celebrity endorse and that give us the answer of the first question of study. At the same time $62.8 \%$ of Yemeni consumers never purchased a brand because it was endorsed by a celebrity. Taking into consideration that the majority of Yemeni consumers which represent $45 \%$ their monthly income were fewer than 200 dollars. Because they think that the product or brand endorsed by a celebrity is of high quality and expensive.

Table 2: Aware of a brand because of a celebrity endorsed

\begin{tabular}{llll}
\hline Variables & Frequency & Percent & Cumulative Percent \\
\hline Yes & 172 & 61.0 & 61.0 \\
No & 110 & 39.0 & 100.0 \\
\hline
\end{tabular}

Table 1: purchase celebrity-endorsed product

\begin{tabular}{lccc}
\hline Variables & Frequency & Percent & Cumulative Percent \\
\hline Yes & 105 & 37.2 & 37.2 \\
No & 177 & 62.8 & 100.0 \\
\hline
\end{tabular}


R. Alawadhi - M. Örs 12/1 (2020) 454-468

\subsection{Exploratory Factor Analysis (EFA)}

The pattern of correlation has the involvement of 6 factors from 24 items, each item factor moves constantly together as a group represents for a particular factor.

Table 4: Pattern and Structure Matrix for Exploratory Factor Analysis

\begin{tabular}{|c|c|c|c|c|c|c|}
\hline & \multicolumn{6}{|c|}{ Component } \\
\hline & 1 & 2 & 3 & 4 & 5 & 6 \\
\hline PhyAttract2 & 1.000 & & & & & \\
\hline PhyAttract3 & .738 & & & & & \\
\hline PhyAttract4 & .803 & & & & & \\
\hline PhyAttract5 & .778 & & & & & \\
\hline TurstW1 & & & .862 & & & \\
\hline TurstW2 & & & .929 & & & \\
\hline TurstW3 & & & .936 & & & \\
\hline Expert2 & & & & & & .840 \\
\hline Expert3 & & & & & & .840 \\
\hline Like1 & & & & .854 & & \\
\hline Like2 & & & & .985 & & \\
\hline Like3 & & & & .852 & & \\
\hline Bimage2 & & .968 & & & & \\
\hline Bimage3 & & .712 & & & & \\
\hline Bimage4 & & .688 & & & & \\
\hline Bimage5 & & .886 & & & & \\
\hline PurchasInt2 & & & & & .982 & \\
\hline PurchasInt3 & & & & & .801 & \\
\hline
\end{tabular}

The items were less than 0.5 and items with cross-loading were excluded. PhyAttract1, TurstW4, Expert1, Bimage1 and PurchasInt1 were excluded due to low communality, low correlations and low factor loading respectively.

\subsection{Confirmatory Factor Analysis (CFA)}

Using AMOS a CFA model was created with a total of 18 observed items of 6 factors after excluded some items in previous phases then the fit indices were examined to evaluate the overall adequacy of the initial measurement model. 


\section{R. Alawadhi - M. Örs 12/1 (2020) 454-468}

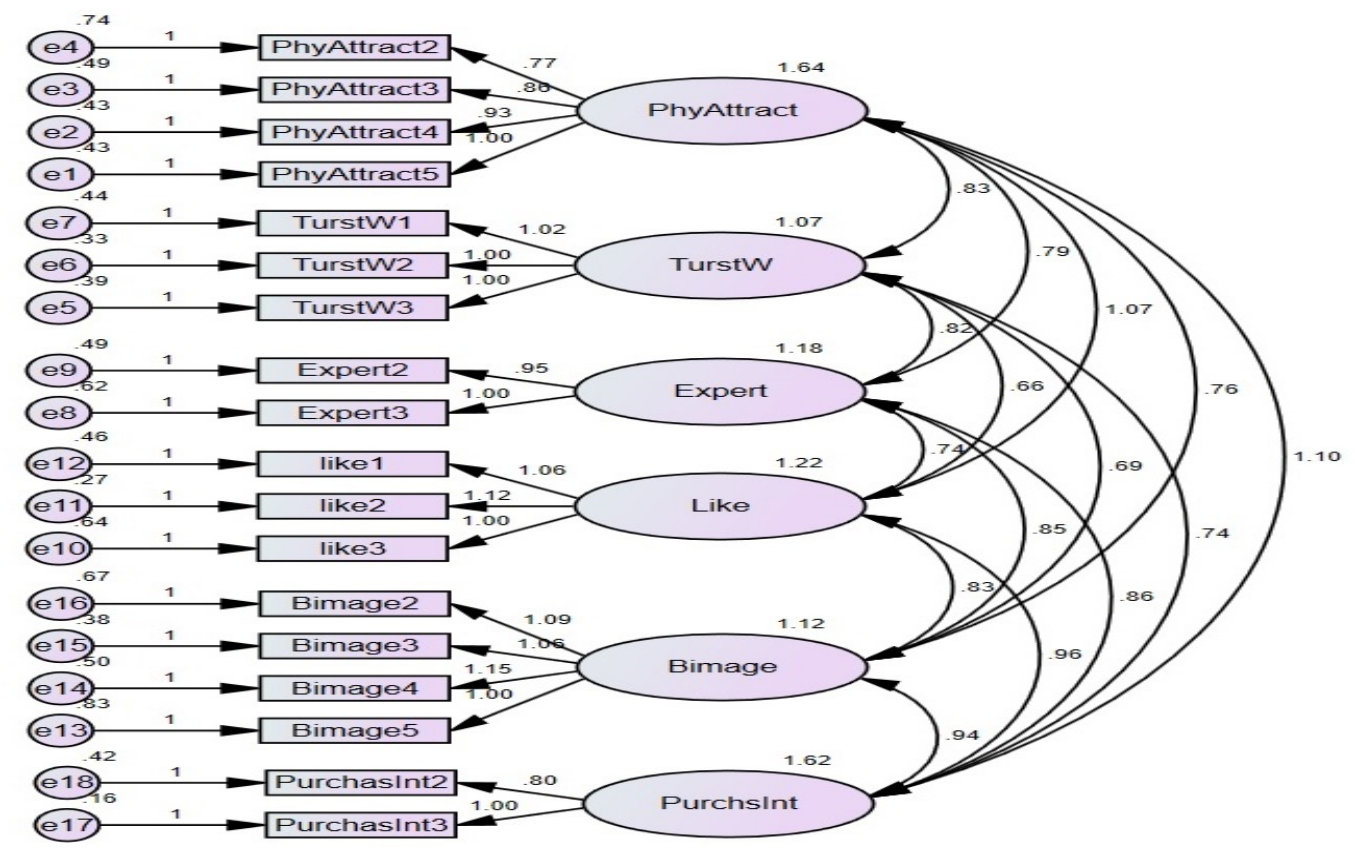

Figure 2: Hypotheses CFA Model

Table 5: Goodness of fit Metrics for CFA model

\begin{tabular}{llll}
\hline Measure & Standard fit & Results of this Study & Remarks \\
\hline CMIN/DF & $<3$ good; $<5$ sometimes Permissible & 1.711 & Good \\
CFI & $>.95$ great; $>.90$ acceptable; & .964 & Great \\
& $>.80$ sometimes permissible & & \\
& $0 \leq$ SRMR $\leq .05$ good & .073 & Acceptable \\
SRMR & $.05<$ SRMR $\leq .10$ acceptable & & \\
& $0.06 \geq$ good & .064 & Good \\
RMSEA & $>.05$ & .059 & Good \\
PCLOSE & & & \\
\hline
\end{tabular}

The results showed that CMIN/DF is well less than the standard fit value of 3, which is 1.711 and indicates a good fit. It is clear the CFI value is equal to .964 which considered greater than the standard fit of .95. SRMR value of .073 is slightly upper the standard fit but is still acceptable. RMSEA and PCLOSE values are .064, .059 respectively, therefore, a good fit for the model.

\subsection{Reliability and Validity}

Referred to reliability as the level that the test scores are empty from measurement error or the elements of errors that happen when testing something. Unreliable measurement will lead to an insignificant correlation between variables and inaccurate results (Muijs, 2004).

Validity concentrates on checking if variables are being measured in an accurate method (Muijs, 2004). To get an acceptable validity you should get an Average Variance Extracted (AVE) above or equal to 0.5 (AVE $\geq 0.5$ ) and a Maximum Shared Variance (MSV) that is lower than the Average Variance Extracted (MSV $<$ AVE). Also, the standard-fit for (CR) should be higher than 0.7 (CR > 0.7) (Gefen and Straub, 2005). 
R. Alawadhi - M. Örs 12/1 (2020) 454-468

Table 6: Validity and Reliability Results

\begin{tabular}{|c|c|c|c|c|c|c|c|c|c|c|}
\hline & $\mathrm{CR}$ & AVE & MSV & $\operatorname{MaxR}(\mathrm{H})$ & Bimage & PhyAttract & TurstW & Expert & Like & PurchasInt \\
\hline Bimage & 0.899 & 0.690 & 0.545 & 0.907 & 0.831 & & & & & \\
\hline PhyAttract & 0.908 & 0.712 & 0.573 & 0.917 & 0.562 & 0.844 & & & & \\
\hline TurstW & 0.894 & 0.738 & 0.537 & 0.895 & 0.632 & 0.626 & 0.859 & & & \\
\hline Expert & 0.803 & 0.671 & 0.545 & 0.803 & 0.738 & 0.569 & 0.733 & 0.819 & & \\
\hline Like & 0.900 & 0.751 & 0.573 & 0.913 & 0.709 & 0.757 & 0.580 & 0.613 & 0.867 & \\
\hline PurchasInt & 0.894 & 0.810 & 0.493 & 0.927 & 0.702 & 0.676 & 0.560 & 0.620 & 0.683 & 0.900 \\
\hline
\end{tabular}

As the table is shown the results of CR is greater than 0.70 also AVE is more than 0.50 and MSV is less than AVE for Discriminant Validity. Lastly, the outcomes that the responses got from respondents are reliable and valid.

\subsection{Structural Equation Modeling (SEM)}

Using the AMOS, SEM was executed on only 17 items. (Figure 3) and (Table 7) presents the goodness-of-fit statistics of a structural model for each specified variable of the study

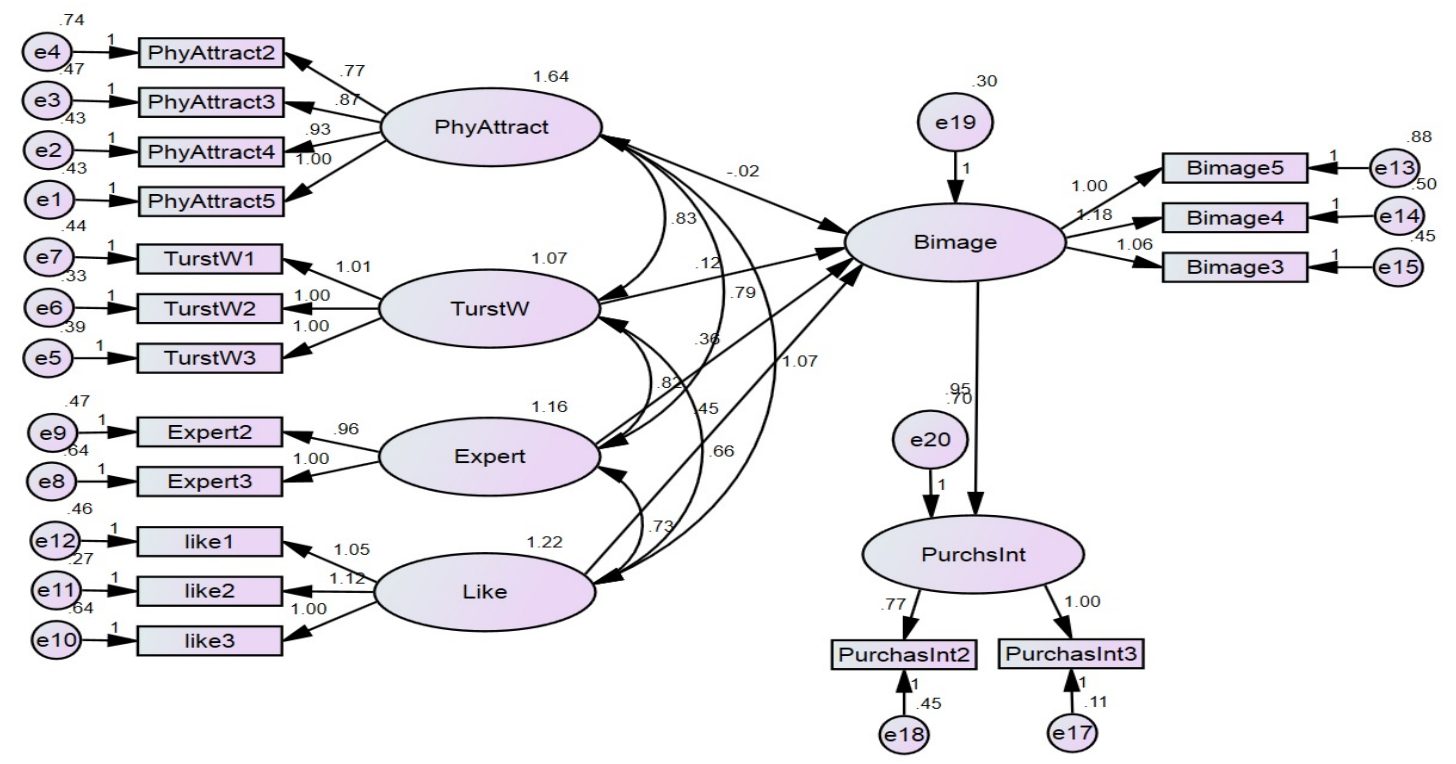

Figure 3: Structural Model

Table 7: Structural Model: Goodness-of-Fit Statistics

\begin{tabular}{cccc}
\hline Measure & Standard Fit & Results of this Study & Remarks \\
\hline GFI & $>.80$ & .888 & Good Fit \\
AGFI & $>.80$ & .842 & Good Fit \\
PGFI & $>.50->.90$ & .627 & Good Fit \\
CFI & $>.95$ great; $>.90$ traditional; & .965 & Good Fit \\
& $>.80$ sometimes permissible & & \\
PCFI & $>.50->.90$ & .776 & Good Fit \\
RMSEA & $0.06 \geq$ & .065 & Good Fit \\
PCLOSE & $>.05$ & .059 & Good Fit \\
\hline
\end{tabular}




\section{R. Alawadhi - M. Örs 12/1 (2020) 454-468}

After excluded Bimage2 item. The findings of the model fit for the structural equation model were as follows: $\mathrm{GFI}=.888, \mathrm{AGFI}=.842, \mathrm{PGFI}=.627, \mathrm{CFI}=.965, \mathrm{PCFI}=.776, \mathrm{RMSEA}=.065$ and PCLOSE $=.059$.

\subsection{Hypothesis Results}

Presented the results of hypotheses testing, some inferences have been made as follows:

Table 8: Hypothesis Result.

\begin{tabular}{cccc}
\hline & Relationship & P-value & Interpretation \\
\hline H1 & PhyAttract $>$ Bimage $>$ PurchsInt & .964 & Not Supported \\
H2 & TurstW $>$ Bimage $>>$ PurchsInt & .414 & Not Supported \\
H3 & Expert $>>$ Bimage $>$ PurchsInt & .012 & Supported \\
H4 & Like $>>$ Bimage $>>$ PurchsInt & .014 & Supported \\
H5 & Bimage $>>$ PurchsInt & $* * *$ & Supported \\
\hline
\end{tabular}

The outcomes showed that there is a powerful and positive relationship between (celebrity expertise, celebrity likeability) and the intent of purchase for Yemeni consumers by mediating of brand image. Considering the results above, $\mathrm{p}$-values $=.021, .014$ sequentially, while (celebrity trustworthiness, celebrity attractiveness) have a negative impact, the p-values $=.414, .964$ sequentially. At last, there is a significant positive relationship between brand image and consumer purchase intention.

\section{FINDINGS AND CONCLUSIONS}

The main goal for any company is building a brand image and raising brand awareness through attract the attention of customer to the brand which effect directly to the intent of purchasing in customers. Companies used celebrity as strategy to get this attention through inform people about a particular product or brand and convince them to buy it. Yemeni consumers are seeing many advertisements in their daily lives. As a result, the marketer should execute effective tactics in advertising to catch target consumers' attention. This study's primary purpose is investigating Yemeni consumers ' perception of celebrity endorsement and to explore the effectiveness of celebrity (trustworthiness, expertise, attractiveness and likeability) on the intention to purchase. Also, discuss the influence of brand image as a mediating between celebrity characteristics and intent of purchase for consumer. However, Most Yemeni consumers regard prominent advertising as an effective marketing strategy. That $61 \%$ of the Yemeni consumers have been aware of a brand just because of a celebrity-endorsed it. That means Yemeni consumers are more attracting by advertisements endorsed a celebrity than non-celebrity. This confirms celebrity endorsement in brand advertisements build a bond in the mind of the customer.

The outcomes showed that a powerful and positive relationship exists between celebrity expertise and the intent of purchase for Yemeni consumers by mediating of brand image. Lots of researches have been done in the impact of the expertise of celebrity to catching customers ' attention. Although the celebrity in the endorsed product is not seen as an expert, their power remains favorable as long as they are experts in their own field. However, Celebrity endorser expertise gives a sense of believability to the brand. Suki's research focused on the role of celebrity endorsement in influencing brands and buying intention for Muslim and non-Muslim consumers. Indeed, Empirical findings from several discriminatory analyses showed that the most important factor for Muslim consumers was celebrity expertise. Over and above, Muslim customers preferred expertise to trustworthiness. The belief of Muslim consumers can be linked to the assumption that products and services endorsed by the celebrity were in line with their Islamic values (Suki, 2014).

Moreover, the results presented that the likeability of celebrities has a strong and positive effect on Yemeni consumers ' buying decisions with regard to brand image. Therefore, the existence of a familiar and likeable celebrity in advertisements increases consumers' purchase intention. In summary, the studies showed that celebrity likability draws the attention to the brand and increases the likelihood that the item will purchase when 


\section{R. Alawadhi - M. Örs 12/1 (2020) 454-468}

the endorser and the customer have a link. In other words, the attractiveness model dimensions that have been conducted in this study conclude that celebrity likability does impact on Yemeni consumers' purchase intentions, whereas celebrity attractiveness does not. based on the research conducted by Roshan and other author, about the effect of celebrity likability in consumer behavior buying in perfume brand, were revealed that celebrity likeability has strongly significant in the perfume buying intention in Colombo and Gampaha in Sri Lanka while the other factors such as lifestyle and familiar face of the celebrity have no relationship in this research study (Roshan et al., 2017).

Furthermore, the results provide a clear understanding of Yemeni's consumer behavior that gives us some ideas and concepts in understanding how celebrity endorser can be chosen through focusing more on celebrity expertise and celebrity likeability to enhance the brand image which finally leads to increase consumer's purchase intention. Nevertheless, this study shows that Yemeni consumers are not interested in celebrities ' external appearance. Which means it's no matter if using an attractive or unattractive celebrity of the brand advertisement in order to get more attention from the Yemeni consumers. Moreover, Yemeni consumers don't trust celebrities.

Finally, it is interesting to observe that the findings of this study are similar to those of Ohaniani's early 1991 report, which showed that while knowledge had a major impact on the buying intention, it had no effect on trustworthiness and attractiveness (Ohanian, 1991). To sum up, when choosing a celebrity to endorse the brand, advertisers must be careful the correct qualities of the endorser often contribute to the consumer's interest and the desire to purchase the item.

From the conclusion and discussion above, it is clear the concern of the Yemeni community to the brand that endorses by a celebrity in an advertisement. That current practice in Yemen can create and increase awareness about the brand and increase intent towards the purchase of the brand. However, this ability probably reduces because of the lack of diversity and the fast growth in celebrity endorser advertising. Wherefore, modern ideas are required to input some variety in the industry. Following is the proposal that marketers should consider regarding celebrity endorsement advertising: To reinforce the company brand believability and increase effectiveness marketers have to use a celebrity who is recognized to have some knowledge about the product that will endorse it. Also, the advertisers must pick celebrity endorsers whose image suits the product attributes and who are perceived by the target consumers to be the actual user of the product. Lastly, the marketers should be smart enough to use celebrities that are likable, familiar and similar to the Yemeni consumers" character and culture.

Every research should have several limitations. Firstly, the sample size used in this analysis was only 282 consumers in Yemen that means unable to generalize the results for all Yemeni consumers. Secondly, this study focused only on four celebrity attributes which were expertise, likeability, attractiveness and trustworthiness. There might other critical celebrity endorser features that impact Yemeni customers' purchase intention a considerable way. Finally, the researcher faced a limited time limit during the study era.

For further researches in the celebrity endorsement filed. It will be interesting to implement the same idea with Yemeni consumers but with a larger sample size for generalization of findings. Focus on the other issues like: celebrity overexposure, celebrity overshadowing, celebrity overuse, and extinction of the celebrity endorser. Moreover, conducting more in-depth studies on the negative influence of celebrity endorsement. Ultimately this study only investigated the mediating effect of the brand image, the moderating influence such as negative publicity could be used as a moderating variable in future research. 


\section{R. Alawadhi - M. Örs 12/1 (2020) 454-468 \\ REFERENCES}

Aaker, J. (1997). Dimensions of Brand Personality. Journal of Marketing Research, 347-356.

Agrawal, P., \& Dubey, S. K. (2012). Celebrities: the linking pin between brands \& their customer. International Journal of Management \& Business Studies, 2(1), 56-60.

Baker , M., \& Churchill, G. (1977). The Impact of Physically Attractive Models on Advertising Evaluations. Journal of Marketing Research, 538-555.

Baseheart, J., \& Miller, G. (1969). Source trustworthiness, opinionated statements, and response to persuasive communication. Speech Monographs .

Byrne, B. (2016). Structural Equation Modeling with Amos: Basic Concepts, Applications, and Programming. New York: Routledge.

Byun, E. (2014). Impact Of K-Pop Celebrity Endorsement On Thai Brand Image. ASBBS Annual Conference. Las Vegas.

Chavda, V. (2015). A study of celebrity endorsement and its effect on buying behaviour of college students in Gujarat. Indian: Shodhganga reservoir of Indian Theses. Retrieved from http://hdl.handle.net/10603/77785

Choi, S. M., \& Rifon, N. J. (2011). It Is a Match: The Impact of Congruence between Celebrity Image and Consumer Ideal Self on Endorsement. Psychology and Marketing, 29(9), 639-650.

Deepa, L., \& Giridhar, K. (2018). Celebrity endorsement and its impact on buying behaviour of college students: A study in Shivamogga city. International Journal of Research in Social Sciences, 8(2), 194-203.

Dubitsky , T., \& Walker, D. (1994). Why liking matters. Journal of Advertising Research, 9-18.

Eisend, M., \& Langner, T. (2010). Immediate and delayed advertising effects of celebrity endorsers' attractiveness and expertise. International Journal of Advertising, 29(4), 527-546.

Erdem, T., \& Swait, J. (2004). Brand credibility, brand consideration, and choice. Journal of Consumer Research, 31(1), 191-198.

Erdogan, B. (1999). Celebrity endorsement: a literature review. Journal of Marketing Management, 15(4), 291-314.

Feick, L., \& Price, L. (1987). The Market Maven: A Diffuser of Marketplace Information. Journal of Marketing, 83-97

Foong, L., \& Yazdanifard, R. (2014). Celebrity Endoresment as a Marketing Tool. Global Journal of Management and Business Research, 37-41.

Gefen, D., \& Straub, D. (2005). A Practical Guide To Factorial Validity Using PLSGraph: Tutorial And Annotated Example. Communications of the Association for Information Systems, 91-109.

Goldsmith, R., Lafferty, B., \& Newell, S. (2000). The impact of corporate credibility and celebrity credibility on consumer reaction to advertisements and brands. Journal of Advertising, 43-54.

Gupta, R., Kishore, N., \& Verma, D. (2015). IMPACT OF CELEBRITY ENDORSEMENTS ON CONSUMERS' PURCHASE INTENTION: A Study of Indian Consumers. Australian Journal of Business and Management Research, 5(3), 1-15.

Hakimi , B., Abedniya, A., \& Zaeim, M. (2011). Investigate the impact of celebrity endorsement on brand images. European Journal of Scientific Research, 116-132. 


\section{R. Alawadhi - M. Örs 12/1 (2020) 454-468}

Horai, J., Naccari, N., \& Fatoullah, E. (1974). The effects of expertise and physical attractiveness upon opinion agreement and liking. Sociometry, 601-606.

Hovland, C., \& Weiss, W. (1953). The influence of source credibility on communication effectiveness. Public Opinion Quarterly, 635-650.

Hovland, C., Janis, L., \& Kelley, H. (1953). Communication and Persuasion: Psychological Studies of Opinion Change. New Haven: Yale University Press.

Hudha, A., \& Hidayat, A. (2009). Study of consumer attitudes towards television advertising using celebrity endorser. Journal Siasat Business, 217-232.

Ind, N. (2007). Living the brand - how to transform every member of your organization into a brand champion. London: Kogan Page Limited.

Jamil, R. A. (2014). Influence of Celebrity Endorsement on Consumer Purchase Intention for Existing Products: A Comparative Study. Journal of Management Info, 4(1), 1-23.

Kambitsis, C., Yvonne, H., Nicholas, T., \& Giannis, C. (2002). Sports Advertising in Print Media: The Case of 2000 Olympic Games. Corporate Communications: An International Journal, 155-161.

Keller, K. (2003). Understanding brands, branding, and brand equity. Interactive Marketing, 5(1), 7-20.

Koshy, L., \& Manohar, J. (2017). Influence Of Celebrity Endorsement On Brand Image Of Grooming Products. International Journal of Multidisciplinary Management Studies.

Maddux , J., \& Rogers, R. (1980). Effects of Sources Expertness, Physical Attractiveness and Supporting Arguments on Persuasion: A Case of Brain over Beauty. Journal of Personality and Social Psychology, 235244.

Mansour, I., \& Diab, D. (2016). The relationship between celebrities' credibility and advertising effectiveness: The mediation role of religiosity. Journal of Islamic Marketing, 148-166.

McCracken, G. (1989). Who is the celebrity endorser? Cultural foundations of the endorsement process. Journal of Consumer Research, 310-321.

Muijs, D. (2004). Doing Quantitative Research in Education with SPSS. London: Sage Publications.

Ohanian, R. (1990). Construction and validation of a scale to measure celebrity endorsers' perceived expertise, trustworthiness, and attractiveness. Journal of Advertising, 19(3), 39-52.

Ohanian, R. (1991). The impact of celebrity spokespersons' perceived image on consumers' intention to purchase. Journal of Advertising Research, 46-54.

Onwujiariri, J., Ateke, B., \& Nnennanya, D. (2015). The Relationship between Celebrity Endorsement and Brand Image in the Fastfood Industry in Port Harcourt, Nigeria. European Journal of Business and Management, 2222-2839.

Pallant , J. (2013). SPSS survival manual. UK: McGraw-Hill Education.

Patel , R., \& Parmar, B. (2015). Fame versus no name: Gauging the impact of celebrities and non-celebrities endorsement on purchase. African journal of business management, 9(4), 1.

Peetz, T. (2012). Celebrity Athlete Endorser Effectiveness: Construction and Validation of a Scale. UNLV Theses, Dissertations, Professional Papers, and Capstones. Las Vegas. Retrieved from http://digitalscholarship.unlv.edu/thesesdissertations/1609 


\section{R. Alawadhi - M. Örs 12/1 (2020) 454-468}

Ranjbarian, B., Shekarchizade, Z., \& Momeni, Z. (2010). Celebrity endorser influence on attitude toward advertisements and brands. European Journal of Social Sciences, 13(3), 399-407.

Reingen, P., Gresham, L., \& Kernan, J. (1980). Behavioral Consequences of the Physical Attractiveness Stereotype in Personal Selling. Chicago: American Marketing Association.

Roshan , P., Sudath , W., Ravindra , D., \& Manoj , P. (2017). Celebrity Endorsement and Consumer Buying Intention With Relation to the Television Advertisement for Perfumes. Management Studies, 5(2), 128-148.

Said, N. P., \& Napi, W. N. (2015). Celebrity And Non-Celebrity Endorsement Effectiveness On Consumers' Attitude Towards Advertisement. International Academic Research Journal of Business and Technology, pp. 5157.

Sallam, M. (2012). Endorser Credibility Effects on Yemeni Male Consumer's Attitudes towards Advertising, Brand Attitude and Purchase Intention: The Mediating Role of Attitude toward Brand. International Business Research, 5(4), 55.

Schumacker, R., \& Lomax, R. (2010). A Beginner's Guide to Structural Equation Modeling. New York: Taylor and Francis Group.

Shimp, T. (2003). Advertising, Promotion and Supplemental Aspects of Integrated Marketing Communication. The Dryden Press, Fort Worth, TX

Suki, N. (2014). Does celebrity credibility influence Muslim and non-Muslim consumers' attitudes toward brands and purchase intention?. Journal of Islamic Marketing, 5(2), 227-240.

Tabachnick, B., \& Fidell, L. (2007). Using Multivariate Statistics. New York: Allyn \& Bacon/Pearson Education.

Thorson, J. (1991). Measurement of Sense of Humor. F. C. Powell.

Ulkhaq, M., Nurdianti, A., Karti, M., \& Astharina, V. (2016). A Confirmatory Factor Analysis Of The Source Model For Celebrity Endorsement. Journal of Management, Marketing and Logistics.

Vaghela, P. (2013). A Study On Consumer Attitude Perception About Celebrity Endorsement. International Journal of Marketing and Technology, 2(12), 150-163.

Williams, B., Onsman, A., \& Brown, T. (2010). Exploratory factor analysis: A five-step guide for novices. Journal of Emergency Primary Health Care (JEPHC), 8(3). 